\title{
THE THEORY AND PRACTICE OF SULH (MEDIATION) IN THE MALAYSIAN SHARIAH COURTS
}

\author{
Ramizah Wan Muhammad
}

\begin{abstract}
This paper attempts to discuss the position of Sulh as a mediation tool to resolve cases brought up in the Shariah Court. The first part of the paper is to explain the importance of Sulh in the institution of justice in Islamic law. Some relevant authorities from the sources of Islamic law will be highlighted including the practice of the companions. The second part of the paper will focus on the status of Sulh in the Shariah Court in Malaysia in terms of history, ethics of the Sulh officer and the procedure of how Sulh takes place in the Shariah Court. The last part of the paper will focus on the Sulh officers including female officers and compare their status with male Sulh officers, nature of cases (e.g divorce, ta'liq, hadānah) handled by the Sulh officers and their success rate. The paper will conclude by a discussion of the possibility of the Sulh officers occupying the position of a judge in the Shariah Court. The last point to be discussed is the balance in terms of number of cases resolved between them.
\end{abstract}

Assistant Professor, Ahmad Ibrahim Kulliyyah of Laws, International Islamic University Malaysia. 


\section{INTRODUCTION}

Sulh is an important mechanism in the Islamic institution of justice. Sulh can be defined as reconciliation or mediation. It is regarded as a painless tool of dispensing justice in many cases especially in the application of divorce cases. ${ }^{1}$ This is a process where disputed parties come for a discussion and will strive to reach a mutually agreed and workable resolution through the assistance from the mediator or Sul $h$ officer. ${ }^{2}$ The purpose of Sulh is to end conflict and hostility among the believers so that they may conduct their relationship in peace and amity. ${ }^{3}$ However, this purpose could only be achieved through a mutual understanding between both parties by looking into the outcome for both families and not solely on individual basis.

Sulh is different with hakam or arbitration where the latter is a process in which disputant parties agree to refer their case to an independent arbitrator who will make a decision for them. The decision given by the arbitrator is binding upon them and legally enforceable. ${ }^{4}$ However, in arbitration, the word decision has been replaced with the word "award." 5 Sulh is a method of dispute resolution of very ancient origin before the advent of Islam where disputes were entrusted to their elders (Kāhin) to decide. ${ }^{6}$

The purpose of this paper is to highlight the importance of Sulh in Islam as prescribed in the Holy Qur'ān and the Sunnah of the Prophet

1

The Straits Times Singapore, $28^{\text {th }}$ April 2007, “New Measures to Ease Divorce Disputes.”

Tuan Atras Mohammed Zin, paper presented at Seminar on Syariah Court Issues, "Family Conflict Resolution in Syariah Court: The Role of Sulh and Its Effectiveness,” organized by Department of Islamic Law, AIKOL, at Moot Court, IIUM, 29th January 2005.

Majid Khadduri, "Sulh," The Enyclopedia of Islam, eds, Clifford Edmond Bosworth, Vol. IX, E.J. Brill, Leiden, 1997, pp. 845-846.

Syed Khalid Rashid, "The Importance of Teaching ADR and Implementing ADR in Malaysia,” Industrial Law Reports, 2000, p. 6. Vincent Powell-Smith, "Settlement of Disputes by Arbitration Under Shariah and at Common Law,” Islamic Studies, Vol. 34, No. 1, 1995, pp. 30-31.

Joseph Schacht, An Introduction to Islamic law, Clarendon Press, Oxford, 1964, p. 10. 
(s.a.w). It is essential to include the duty and roles of the Sulh officers as the mediators in the Sul $h$ process. This discussion includes the female Sulh officer in Shariah Court in Malaysia. This paper is divided into two parts; First part deals with the importance of Sulh in Islam and administration of Shariah Court in Malaysia. The second part deals with Sul $h$ in Malaysia and roles and status of Sul $h$ officers including female officers.

\section{SULH IN ISLAM}

Sulh is derived from the word salaha, which means to do good deeds. According to Syed Sābiq, Sulh, literally means to settle any dispute. ${ }^{7}$ The word Sulh can be categorized as a method or mechanism to settle the dispute amicably. Sul $h$ can also means an agreement between two parties by relying on the prescribed conditions, which they have agreed to earlier on in the process of settling their disputes. According to Ibn Qudāmah, Sulh is an agreement between two disputed parties which would lead to peace. ${ }^{8}$ In Islam, the process of Sulh can be done in all cases except in Hudud cases.

The word salaha and its derivatives have appeared 179 times in the Holy Qur'ān. ${ }^{9}$ However, the word Sulh itself appears only once. ${ }^{10}$ In this verse, Allah had clearly prescribed that Sul $h$ is the best. ${ }^{11}$ There are 4 verses in which Allah commands us to reconcile and make peace

7 Syed Sabiq, Fiqh al-Sunnah, Vol. 3, Dār al-Diyān li at-Turāth, Kaherah, 1990, p. 389.

8 Ibn Qudāmah, al-Mughn̄̄, Vol. 4, Maktabah Tijāriyyah, Makkah, 1984, p. 351.

For example, șalaḥa, așlaḥa, Muṣliḥ. See Muhammad Fuad Abdul Baqi, “Mu’jam al Mufahras Li al Alfāz al Qur’ān al Karìm,” Maktabah Islamiyyah, Istanbul, 1983, pp. 410-412.

Al-Qur’ān, Sürah Al Nisā’ (4): 128 “And Such Settlement is Best; Even Though Men's Souls are Swayed by Greed.”

11 In Saudi Arabia the great majority or 99\% of all civil cases filled in Saudi Islamic Courts end in reconciliation. They often quote the maxim "Ṣulh is Best.” See Walid Iqbal, "Dialogue and the Practice of Law and Spiritual Values: Courts, Lawyering, and ADR: Glimpses into the Islamic Tradition,” Fordham Urban Law Journal, Vol. 28, April, 2001, p. 1040. 
between two disputed parties. The first two verses are in sürah al Hujurāt on the issue of al Baghyu crime where Allah says to the effect:

If two parties among the believers fall into a fight, make peace between them; but if one of them transgresses beyond bounds against the other and fight all against the one that transgresses until it complies with the command of Allah, but if it complies, then make peace between them with justice and be fair; For Allah loves those who are fair and just. ${ }^{12}$

The next verse is also from the sürah al Hujurät where Allah says to the effect

The Believers are but a single brotherhood: So make peace and reconciliation between your two (contending) brothers; and fear Allah that you may receive mercy. ${ }^{13}$

The last verse pertaining to this issue is in the first verse of sürah al Anfāl over the issue of booty. Allah says to the effect:

They ask you concerning (things taken as) spoils of war. Say: such spoils are at the disposal of Allah and the Messenger: So fear Allah and keep straight the relations between yourselves: Obey Allah and His Messenger if you do believe. ${ }^{14}$

Abdullah Yusuf Ali had translated the word "wa așlihu” as keep straight. In other words, in the course of getting worldly gains, the internal relations of Muslims are to remain staunch to the cause of Allah and His Messenger. ${ }^{15}$

\footnotetext{
12 Al Qur'ān, Sūrah al Hujurāt (49):9.

13 Al Qur’ān, Sūrah al Hujurāt (49):10.

14 Al Qur'ān, Sūrah al Anfāl (8):1.

15 Abdullah Yusuf Ali, The Holy Qur'ān: English Translation of the Meaning and Commentary, King Fahd Holy Qur'ān Printing Complex, Madinah, 1990, p. 469.
} 
In another verse on the issue of Qisās,${ }^{16}$ Allah prescribes that the punishment for a murderer is Qișas or retaliation, however, if the family of the victim pardons the murderer then there should be compensation given to the former. This verse did not use the word salaha or Sulh, but the whole context of this verse is to be understood that the right to pardon the accused was given to the family of the victim and finally to make peace between them. ${ }^{17}$ Ibn Abbas also reported that the above verse is to show that $S u l h$ is one way to achieve justice and peace between two parties. ${ }^{18}$

In one hadith, the Prophet (s.a.w) was reported to have said that:

He who causes intentionally the death of another, it is left to the family of the deceased to decide on Qișās or the taking of Diyah... and if they agree on Sulh, it is for them. ${ }^{19}$

This hadith shows that despite the fact that the prescribed punishment is qișạs as the right of Allah but it is the right of the individual to decide on Sul $h$ based on the facts and circumstances of the case. The ruling in Islamic law is that it permits the taking of law of retribution (qișass) for the injuries or death that one suffered. However, what is occasionally overlooked is that Islam places a strong emphasis on the need of Sul $h$ between the perpetrators if possible. According to Ibn 'Arabī, the interpretation of Sūrah al Baqarah verse 179 should be as follows:

O people of understanding, by having the right of retaliation, you are handling a life in your hands so it is better for you to reach a Sul $h$ with a criminal. ${ }^{20}$

\footnotetext{
16 Al Qur'ān Sūrah al Baqarah, (2):178-79.

17 Muhammad Iqbal Siddiqi, The Penal Law of Islam, International Islamic Publishers, New Delhi, 1995, p. 151.

18 Ibn Rushd, Bidāyah al Mujtahid wa Nihāyat al Muqtaṣid, Vol. II, Dār al Fikr, Beirut, 2001, p. 307.

19 Cited in Ali Ahmad, "Compensation in Intentional Homicide in Islamic Law,” Journal of Islamic and Comparative law, 1980, p. 40.

20 Cited in 'Abd al Qāder 'Awdah, Tashrī‘ al Jinà’i, Vol. 2, p. 259.
} 
This is the $S \bar{u} f \bar{l}$ approach that the relatives of the victims should strive to reach a Sul $h$ with a criminal rather than asking for the application of retaliation. They also regard the criminal as a sick person who needs mercy and compassion. ${ }^{21}$ Ibn 'Arabī also mentioned that the word ${ }^{c} a f w$ in sürah al Baqarah verse 178 means that family of the victim can make an offer and gift, to the murderer and demand for diyah instead of qișās. ${ }^{22}$

\section{ADMINISTRATION OF THE SHARIAH COURT IN MALAYSIA}

Given the importance of Sulh in Islam, it is right to place Sulh process under the jurisdiction of the Shariah Court in Malaysia. The Shariah Court in Malaysia is becoming more developed and systematic compared to the 1980s. In 1948, the Shariah Court was placed separately from the Federated Malay States ${ }^{23}$ and was at the bottom after the Penghulu Court and the Magistrate's Court. It was known as Kathi Court. ${ }^{24}$ The subordinate position given to the Shariah Court in the early days before and after independence has to a certain extent empowered Civil Courts to override their decisions. ${ }^{25}$ However, with the passage of time, the Shariah Court has been structured and positioned in a more remarkable place.

The separation of the Shariah Court from the Council of Muslim religion, ${ }^{26}$ the introduction of a number of substantive laws or enactments

$21 \quad$ Suleyman Derin, “The Tradition of Sulh among the Sufis: With special reference to Ibn 'Arabī and Yunus Emre,” Journal of Academic Studies, Vol. 7, No. 27, Nov. 2005-2006, pp. 3-4.

22 Ibn Al 'Arabī, Aḥkām al Qur'ān, Vol. 1, Dār al Kutub, Beirut, 1957, p. 66.

23 Ahmad Ibrahim, “Shariah Court in Malaysia” the Malayan Law Journal, 1986, 2 MLJ, p. cxxxiii.

24 See section 4 of the Selangor Administration of Muslim Law Enactment 1952, section 7 of Kelantan Courts Enactment 1955.

25 Section 45 (6) of the Selangor Administration of Muslim Law Enactment 1952.

26 Abdul Monir Yaacob, “Undang-undang Pentadbiran Agama Islam: Pengkanunan, Reformasi dan Penyelarasan,” IKIM Law Journal, Vol. 2, No. 2, 1998, p. 75. 
and procedure, the hierarchy of Shariah Courts ${ }^{27}$ and the establishment of Jabatan Kehakiman Syariah Malaysia or Shariah Judicial Department of Malaysia (JKSM), at the state and federal level are indicators that the Shariah Court in Malaysia ${ }^{28}$ now occupies a rightful place.

Philosophically, the Shariah Court is a place to abolish persecution and cruelty and ultimately to uphold justice. ${ }^{29}$ The function of the Shariah Court will always be as an institution for the upholding of truth and justice in a professional, effective, efficient and modern manner. The Shariah Court is a place to dispense justice according to hukum syara'. However, hukum syara' in the context of Malaysia means Islamic law which has been defined according to the specific jurisdiction by virtue of the Federal Constitution of Malaysia. The Shariah Court, just like any other court in Malaysia, is a place to administer justice and to have a proper trial ${ }^{30}$ in a court. A trial is a process that would take longer time and needs to follow certain court procedures.

Jabatan Kehakiman Syariah Malaysia (JKSM) since its establishment, has formulated a number of methods and mechanisms so that the case will be settled as soon as possible. One of the objectives of JKSM is to give efficient treatment to each case and at the same time, to ensure it goes to trial not more than 21 days after the date of registration. ${ }^{31}$

There are quite a number of improvements that have been introduced in the course of promoting and structuring the Shariah Court in Malaysia. Improvements have been in aspects relating to the form of the physical structure of the Shariah Court, the number of judges, number of staff and administration of the Shariah Court.

$27 \quad$ Ahmad Ibrahim, “Kedudukan Undang-Undang Islam di Malaysia,” Jurnal Hukum, No. 1, 1997, p. 126.

28 Buletin JKSM, Bil. 1/2000, Jabatan Kehakiman Syariah Malaysia, Kuala Lumpur, 2000, p. 8.

29 Datuk Sheikh Ghazali Bin Haji Abdul Rahman, "Masa Depan Mahkamah Syariah di Malaysia: Cabaran dan Strategi Dalam Masyarakat Majmuk," Jurnal Hukum, Jun 2007, p. 168.

30 Trial means a judicial examination, in accordance with law, of a cause either civil or criminal, of the issues between the parties, whether of law or fact, before a court that has jurisdiction over it. See Avtar Singh, College Law Dictionary, wahwa Nagpur, New Delhi, 2004, p. 6578.

31 Arahan Amalan (Practice Direction) No. 2/2001, Jabatan Kehakiman Syariah Malaysia, $2^{\text {nd }}$ February 2001 by Datuk Sheikh Ghazali Bin Haji Abdul Rahman, Director General of JKSM. 
There are two ways in commencing civil actions in the Shariah Court i.e. there is a claim ${ }^{32}$ to be made to other parties and application ${ }^{33}$ to be made by the applicant. However, if the claim is made to the court, then the case will be registered. The registrar will have to decide whether the case is eligible for trial by looking, among other things, into the statement of claim, nature of the claim, procedures and potential witnesses.

Administration of the Shariah Court in Malaysia is a vital component in ensuring that justice is achieved. Administration could be in the form of adequate laws or enactments to try a case, procedures, courts, number of judges and so forth. One of the normal ways to achieve justice in the legal system is to have a court trial as soon as possible. The saying goes, justice delayed is justice denied. ${ }^{34}$ However, one has to take note that, justice in a court trial or hearing can only be done after all parties are ready to have a trial or hearing together with the relevant documents, witnesses, evidence, judge, lawyers and even the court! These may take some time. Hence, court trial is not the only method of achieving justice in the Islamic legal system. To a certain extent, regular court trials are bypassed and a parallel set of institutions are called upon for assistance, such as Sulh.

\section{SULH IN MALAYSIA}

Sulh had long been adopted as one mechanism to resolve disputes among the Malays since 1600 s or earlier. ${ }^{35}$ The headman or

$32 \quad$ Claim means a proceeding made to the Shariah Court together with a writ of summons to be served to other parties. For example a claim on harta sepencarian, maintenance etc.

33 Application is a process to apply for an action where there is a specific form to be filled and among these are applications to get a consent for the solemnization of marriage, application to get a wali hăkim. See Act 585 Shariah Court Civil Procedure (Federal Territories) Act 1998 Second Schedule.

34 The quote by William Gladstone, British Statesman (1809-1899). See http://en.wikiquote.org/wiki/William_Gladstone.

35 Sakin J \& Robin W. Winks, Malaysia: Selected Historical Readings, Oxford University Press, Kuala Lumpur, 1966, pp. 78-83. 
Imām administered this process in each village. Normally, the headman dealt with agricultural and community disputes and the Imām was in charge of family disputes. In fact, once a person is appointed as a leader, he or she indirectly has to deal with the problems of his community. As such, some of the headmen or Imām were fulfilling the duty as mediators reluctantly. This job was done in an unofficial manner and they were non- assertive mediators. ${ }^{36}$

The Sul $h$ process was officially introduced in the Shariah Courts in Malaysia in 2001. The Federal Territory Shariah Court, Kuala Lumpur was the first to operate this pilot project. This was followed by Selangor in June 2002 and Malacca in September 2002. ${ }^{37}$ The number of states which have adopted this process have increased including Negeri Sembilan and Pulau Pinang. ${ }^{38}$

Sulh can be categorised as a process where the disputed parties in any relevant case are called to the proper session (Majlis) ${ }^{39}$ organised by the Shariah Court following a proper procedure. Supposing that a settlement has been achieved, an agreement will be signed by both parties based on the stipulated conditions which they have agreed earlier in the Majlis. The agreement will be prepared and signed by both parties. Later, it will be issued as a court's order, whether, by the Syariah Subordinate Court judge or Syariah High Court judge. ${ }^{40}$

The concept of Sulh in Malaysia is quite different from what the classical Muslim jurists had discussed. The differences relate to the procedure prior to the Sulh session and after the session is over. Each case has to be registered in the Shariah Court and will be evaluated by the Court Registrar. The second difference concerns the scope of Sulh. The scope of Sulh pertains to matrimonial matters within and after the marriage including maintenance, jointly acquired property, custody of children, mut 'ah etc. The Sul $h$ process is assigned under the jurisdiction

36

James A. Wall \& Ronda Roberts Callister, "Malaysian Community Mediation,” Journal of Conflict Resolution, Vol. 43, 1999, p. 361.

Tuan Haji Mohamad Bin Abdullah, "Pelaksanaan Sulh di Mahkamah Syariah,” Jurnal Hukum, Vol. XVI, No. 2, 2003, p. 68 and p. 81.

There are some states which already have allocations for the post but yet to be filled such as Perak and Pahang. Rule 5 of Shariah Court Civil Procedure (Sulh) Federal Territory Rules 2004.

See section 94 of the Syariah Civil Procedure Act. 
of the Syariah Subordinate Court and High Court in the respective states in Malaysia.

The legal provisions of Sulh as a method of settling disputes are provided in each state. Among others are the Shariah Court Civil Procedure (Sulh) Federal Territory Act 585 Rules 2004, Syariah Court Civil Procedure (Sulh) Malacca Rules 2004 and Shariah Court Civil procedure Enactment, Selangor 2003. ${ }^{41}$

Section 99 of the Federal Territory Rules reads as follows:

The parties to any proceedings may at any stage of the proceedings, hold Sulh to settle their dispute in accordance with such rules as may be prescribed or in the absence of such rules, in accordance with Hukum Syara'.

Rule 3 of the Civil Procedure Rules mentions that it is the duty of the Registrar of the Shariah Court to look into the case and use his discretionary power to decide on the date and to issue the notice of the Sulh session. ${ }^{42}$

According to Practice Direction No. 3 year 2002, JKSM has directed that for each case, which is eligible for Sulh, notice must be issued not more than 21 days after it was registered. ${ }^{43}$ This is to ensure that justice can be assured through a speedy Sulh process.

The Sulh process is a practical and successful method that is showing a remarkable change for the administration of the Shariah Court

$41 \quad$ Just to name a few states.

42 Where, after receiving a summons or an application for any cause of action, the Registrar is of the opinion that there is a reasonable possibility of a settlement between the parties to the action, the Registrar-

a) shall not fix a date for the trial of the action within a period of three months from the receipt of the summons or the application;

b) shall fix a date, as soon as practicable, for the parties to hold Sulh; and

c) shall serve the notice for the date fixed for Sulh on the parties.

43 Tuan Mohamad Bin Hj Abdullah, "Pelaksanaan Șulh di Mahkamah Syariah,” ibid. 
in Malaysia. It was reported that since the introduction of Sulh in 2001, $70 \%$ of cases have been resolved through it and it managed to reduce the backlog of cases. ${ }^{44}$ The Legal Aid Bureau is also adopting this system since the Legal Aid (Mediation) Regulations 2006 came into force in September last year. ${ }^{45}$ As a matter of fact, the backlog of cases varies from one state to another. ${ }^{46}$ However, there is much hope that the Sulh process will eventually clear all the delays and justice will be served for the disputed parties.

\section{SULH OFFICERS IN MALAYSIA}

Since Sul $h$ is an important and fast method to resolve disputes in the Shariah Court, the status of the Sulh officer as a problem solver should be taken care of in the administration of the Shariah Court in Malaysia.

The Sul $h$ officer is called a Chairman throughout the Process. ${ }^{47}$ However, it was suggested that amendment should be made to replace the word Chairman with the word Sulh Officer. $^{48}$ The writer strongly believes that, in view of the importance of the role played by them, it is essential to recognize his title as "Sulh officer" in terms of status, position and post in the Shariah Court. This post has to be created in every Syariah Court in Malaysia and given permanent status. At the same time, it is

\footnotetext{
$44 \quad$ The Star, 28 ${ }^{\text {th }}$ December 2006, "Mediation Reduces Backlog."

$45 \quad$ News Straits Times. 21 ${ }^{\text {st }}$ February 2007, "Mediators to Help Clear Backlog of Cases.”

46 Zaleha Kamaruddin, "Delays in Disposition of Matrimonial Cases," IIUM Law Journal, Vol. 7, No. 1, 1999, p. 195.

$47 \quad$ Rule 5 of the Syariah Court Civil Procedure Sulh (Federal Territories) Rule 2004.

(4) The Chairman shall, where possible, assist the parties to resolve the dispute concerning the subject matter of Sulh and shall give each party an opportunity to be heard

(5) In a Majlis Sulh, the Chairman may take evidence from the parties, accept any document submitted and may, if he thinks necessary, adjourn the Majlis Sulh from time to time.

48 Tuan Atras Mohamad Zin, "Family Conflict Resolution in Shariah Court: The Role of Șul $h$ and its effectiveness,” ibid, p. 16.
} 
necessary to ensure each Shariah Court has their own Sulh officer without trying to delegate the power to the registrar or any other officer of the Shariah Court. ${ }^{49}$

In Shariah Courts in Malaysia, there are 29 Sulh officers..$^{50}$ Out of the 29 there are 5 female Sulh officers working in Selangor and Federal Territory. This is quite a small number of female officers. However, despite a small number, one of them hold a better grade compared to their male counterparts. ${ }^{51}$

Sulh officers in the court institution are not confined to just holding sessions for the Sulh Process. Some of them have been given "Tauliah Hakim"52 to act on behalf of judges if the latter is on leave or attending a course. The purpose of doing so is to ensure that there will be no delay in hearing the case and ultimately to follow the practice of fixing a trial date within 21 days.

To date, no woman has held the judge's post..$^{53}$ However, it's interesting to know that in Shariah Cout in the state of Kelantan, there are some female Sulh officers who have been given tauliah hakim. ${ }^{54}$ Technically, a Sul $h$ officer could become a judge, have a trial, and give a judgment provided he has the tauliah hakim. ${ }^{55}$

$49 \quad$ It happened in Shariah Court in Malacca, when the registrar had to hold the session. An interview with Tuan Haji Mohamad Bin Abdullah, Chief Registrar at his office, JKSM, Putrajaya, on 27 ${ }^{\text {th }}$ April 2007, 11.45 am.

9 in Selangor, 4 in Malacca, 3 in Federal Territories, 7 in Negeri Sembilan and 6 in Pulau Pinang. Source from Puan Laila Busyra Hassan from JKSM, Putrajaya, 10 $10^{\text {th }}$ May 2007. Puan Ruzita Ramli is the Sulh officer in the High Court and Subordinate Court in the Federal Territory. The grade she is holding is LS 44 which is equivalent to a Syariah Subordinate Court judge. Interview conducted at her office, Federal Territory Shariah Court on $8^{\text {th }}$ of May 2007.

52 Literally, it can be translated as a letter of appointment to act on behalf of judge.

53 Interview with Tuan Haji Mohamad bin Abdullah, Chief Registrar of JKSM, ibid.

$54 \quad$ This information was given by an officer from JKSM, $2^{\text {nd }}$ April 2008.

55 For example, Tuan Atras Mohamad Zin is Acting Syariah Subordinate Court judge in Shah Alam, Selangor. However, the post that he holds is Sulh Officer. 
In order to help the Sul $h$ officer manage the Sulh session, there is a Sul $h$ Working Manual ${ }^{56}$ for the Sul $h$ officers as a guideline throughout the process. According to the Manual, the Sulh officer will first, have an introduction with all the parties including himself and explain the purpose of having the Sulh session. Later, the Sulh officer will recite the sürah al Fätihah and prayer. However, according to one related experience, a female Sulh Officer recited the doa for all the parties including male which raised eyebrows. As such, the female officer skips the doa but begins the session with sürah al Fätihah.

The next step would be to remind all the parties to observe certain rules in the course of the process, such as each party to be given an opportunity to talk, and whenever one party is talking, the other one should listen without interruption. This is to ensure that calm and peace is maintained throughout the process. The Sulh officer would always remind the parties that they are not forced to agree on anything. They must try to understand each other's problem but not at the expense of one's right. ${ }^{57}$

After the reminder is read, there will be submission by the parties in dispute at the joint meeting. They can express the issue and describe the main problem if they cannot comply with it. They can state the reasons they have to agree or not to agree. If the joint meeting does not work, then the Sul $h$ officer can ask one party to leave the session and conduct the session with one party in attendance. ${ }^{58}$ This is done through the discretionary power of the Sulh officer by looking into any anticipated situations that may prolong the case.

The duty of the Sul $h$ officer is a facilitator in the process so that both parties are satisfied with the process and achieve an amicable result. Hence, the officer is always reminded that if the process is not successful, it is not the fault of the officer. The objective of the Sulh process is to

\footnotetext{
$56 \quad$ Manual Kerja Șulh.

57 However, some parties claimed that they were forced to agree or not agree on something. See Mohd Naim Mokhtar, “Alternative Dispute Resolution (Sulh) in the Federal Territory Syariah Court in Malaysia,” paper presented at International Family Law Conference, 2007, organized by Ahmad Ibrahim Kulliyyah of Laws, International Islamic University Malaysia \& JKSM on 16-17 ${ }^{\text {th }}$ January 2007.

58 This is known as Caucus meeting.
} 
create a just process for both parties to discuss as well as to negotiate and not merely to achieve an agreement. ${ }^{59}$

Mediation or the Sul $h$ process has four fundamental and universal characteristics, as follows:

1. neutrality or impartiality of the mediator;

2. voluntariness of the process;

3. confidentiality of the relationship between the mediator and the parties;

4. procedural flexibility available to the mediator. ${ }^{60}$

The success of the process depends upon the disputants who are willing to solve the dispute and show commitment towards it. Both parties must also have a "give and take" attitude. This is where the second element, voluntariness, plays its role. They must be honest and are recommended to express what they feel and what they cannot or they can do. ${ }^{61}$ This is in view of getting the whole idea of the case. Apart from this, it is the duty of the Sulh officer to use his or her soft skills to stimulate the conversation and to generate ideas so that the parties can discuss the matter freely. ${ }^{62}$

It was suggested that female Sulh officers are better qualified to hold the post because they are more patient and are motherly throughout the process and are able to cope with a number of issues in the case. ${ }^{63}$ This is not the case for male officers.

It is vital for every Sul $h$ officer to undergo certain training and courses from time to time. However, the training should not be confined

$59 \quad$ Mohd Naim Mokhtar, “Alternative Dispute Resolution (Sulh) in the Federal Territory Syariah Court.” Ibid, p. 8.

Nora Abdul Hak, Islamic Arbitration (Tahkim) and Mediation in resolving Family Disputes- A Comparative Study Under Malaysian and English Law, Unpublished Ph.D Thesis, Glasgow Caledonian University, United Kingdom, 2002, p. 143.

61 Tuan Mohamad Bin Hj Abdullah, "Pelaksanaan Șulh di Mahkamah Shariah," ibid, pp. 77-78.

62 Sometimes the female Sulh officer was accused of being bias to the female parties. 
to local ones but must be extended to overseas training in view of obtaining exposure and gaining experience especially, psychology skills with a variety of people.

In terms of number of cases per day, Sulh officers managed to settle 6 cases per day. In average, each couple may bring 3 cases, hence 6 cases are equivalent to 3 couples per day. However, there was a case where a female Sulh officer managed to settle about 10 cases per day. This is an achievement when she managed to clear the backlog of cases in the Selangor Shariah Court. ${ }^{64}$

\section{ETHICAL CODE FOR SִULH OFFICERS}

The ethical code was introduced in $17^{\text {th }}$ July 2002. This code is meant to govern the conduct of the Sulh officer during handling the process and throughout his tenureship as a Sulh officer. The Code is divided into two parts. The first part deals with general responsibilities of Sulh officer when holding the post. Among the responsibilities are that he is not to indulge in behaviour that would jeopardise the sacred name of the Shariah Court as an institution of justice. He or she is not allowed to socialise in a suspicious situation where his or her credibility as a person to uphold justice is questioned. A Sulh officer is also forbidden to accept any gifts under any circumstances, which are related to his post. These are some of the dos and don'ts for them to observe. They are however, encouraged to increase their knowledge and enhance their skills from time to time. They must try to have the session as soon as possible.

The second part of the code, provides special responsibilities for a Sulh officer while conducting the Sulh process. Among others, the officer is not allowed to conduct the case while he or she is unwell, hungry or angry. He or she is also not allowed to hear any case of his enemy or his friends to avoid bias in facilitating the case. It is vital for the Sul $h$ officer to show a positive attitude while conducting the case.

It is interesting to say here that the ethical code for Sul h officers is almost the same with the Ethical Code for Shariah Court Judges. In

\footnotetext{
64 Interview with Puan Siti Noraini Mohd Ali, Șulh Officer at the Selangor Syariah Subordinate Court at her office, Gombak Timur on the $7^{\text {th }}$ of May 2007.
} 
other words, one could infer that the Sulh Officer is actually acting like a judge. The code of conduct, which he is supposed to observe, is similar with judges. The difference is only the power: the judge has power to issue a court order or sentence, the Sulh officer has no power to do that, instead he is the mediator to the disputing parties so that they can solve their problems in an amicable way. One should not forget that the scope of both jobs is still the same; to dispense justice. This is the backbone of the judicial institution.

In Kitāb al Aḥkām al Sulțāniyyah, Imām al Māwardī had written on the Ethics of the Judge (adab al qãdi). He has divided the $a d a b$ into two parts: general responsibilities and special responsibilities. ${ }^{65}$ These responsibilities are also categorised as the ethics for inside and outside the court. ${ }^{66}$ As such, one could say here that Sul $h$ officers and the shariah court judges are the same in terms of the purpose of managing the job. They differ only in technical matters. Some of the Sul $h$ officers, however, do not hold the post on a permanent status but on contract basis. ${ }^{67}$

\section{CONCLUSION}

The fast growing need for human interest in their daily lives including settling the case is something that we should be concerned about. However, in the institution of justice, the fast rule is not the formula, if no relevant documents are there and relevant persons could not be reached. Nevertheless, it is indeed our main concern to see the disputant parties to settle the case amicably. Based on the number of cases, which have been resolved through $S u l h$, it is indeed important for some of us to opt for this mechanism in deciding a case. One also has to take note that the backlog of cases does not only happen in the Shariah Court but in Civil Courts as well. ${ }^{68} \mathrm{JKSM}$ will from time to time improve the process

\footnotetext{
$65 \quad$ Al Māwardī, Kitāb al A hḷāmm al Sulțāniyyah, translated by Asadullah Yates, Ta Ha Publisher, 1996, p. 78.

66 Ahmad Ibrahim \& Mahmud Saedon Awang Othman, "Judges and Lawyers under the Shariah,” in Islam and Justice, ed. Aidit bin Haji Ghazali, IKIM, Kuala Lumpur, 1993, pp. 134-136.

67 Interview with Tuan Haji Mohamad Bin Abdullah, ibid.

$68 \quad$ News Straits Times, $18^{\text {th }}$ June 2007, “Good and Bad News on Backlog."
} 
and enhance the skills of Sul $h$ officers. The status of Sul $h$ officers in the administration of the Shariah Court is very important and as such should be restructured. They complement the judges in the Shariah Court in handling disputes. Furthermore, the existence of Sulh officers actually help to reduce the workload of judges and to create a scenario of tolerance among the society. According to Ibn Farhūn, "know that the Islamic judicial institution is the most powerful and the most venerable office. The judge is the key element of judgement and he is responsible for all aspects of $Q a d \bar{a}^{\prime}$ - no matter how large or small, without limitation. ${ }^{69}$ This saying is an acknowledgment of the extraordinary responsibility of the Shariah Court judge in the multiple roles he plays as a mediator and judge. This is what happened in the Shariah Court in Malaysia where Sulh officers are given tauliah hakim and to take place of the judge when he is absent. The qualification of a Syariah Subordinate judge is the same with a Sulh officer. Thus, trust has been given to a Sul $h$ Officer to hold the post of judge.

69 Ibn Farhun, Tabsirat al Hukkam, Vol. 1, Dar al Kutub, Beirut, 1995, p. 93. 


\section{SULH PROCESS}

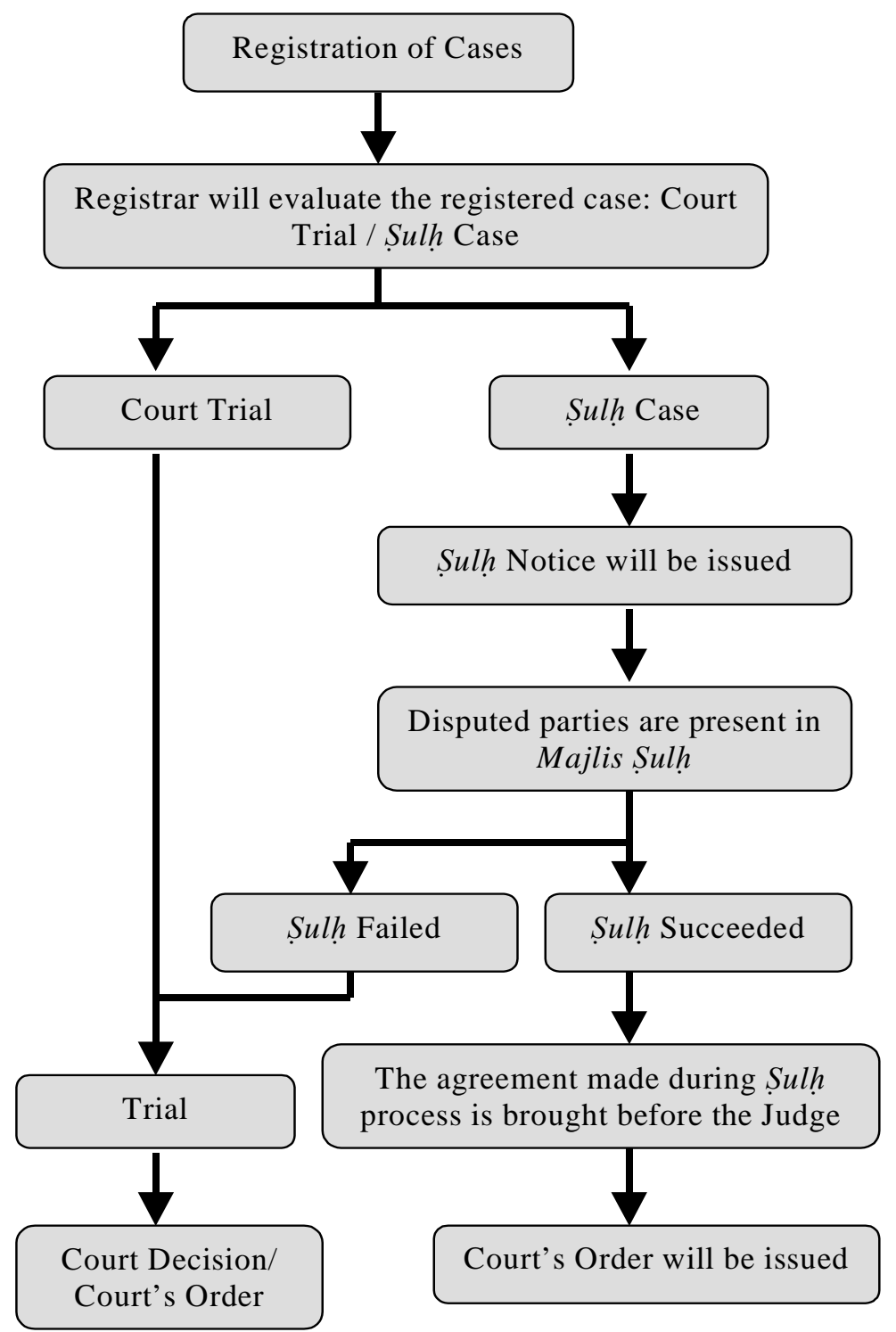

